\title{
Yield and morpho physical characters of some modern aus rice varieties at Khagrachari
}

\author{
Sushan Chowhan ${ }^{1 *}$, Md. Khan Jahan $\mathrm{Ali}^{2}$, Kamrun Nahar ${ }^{2}, \mathrm{Md}$. Moshiur Rahman ${ }^{2}$, Md. Ibrahim $\mathrm{Ali}^{3} \&$ \\ Majharul Islam ${ }^{4}$ \\ ${ }^{1}$ Adaptive Research and Extension Division, Bangladesh Institute of Nuclear Agriculture, Substation, Ishurdi, Pabna-6620, Bangladesh \\ ${ }^{2}$ Plant Breeding Division, Bangladesh Institute of Nuclear Agriculture, Sub-station, Ishurdi, Pabna-6620, Bangladesh \\ ${ }^{3}$ Agronomy Division, Bangladesh Institute of Nuclear Agriculture, Mymensingh-2202, Bangladesh \\ ${ }^{4}$ Soil Science Division, Bangladesh Institute of Nuclear Agriculture, Mymensingh-2202, Bangladesh \\ *Email: sushan04@yahoo.com
}

\section{ARTICLE HISTORY}

Received: 07 October 2020

Accepted: 25 December 2020

Published: 15 January 2021

\section{KEYWORDS}

Drought

Binadhan-14

Agronomic performance

Khagrachari

CHT
ABSTRACT

Aus, aman and boro are three rice cultivating seasons in Bangladesh. Among these aus is the least cultivated and grown in comparatively small scale due to prevailing drought and less availability of surface water for irrigation. Modern varieties of aus rice cover a significant area of the country conversely local cultivars cover a small area. Aus rice requires much fewer inputs than aman and boro. Due to continuous declination of groundwater level, nowadays more emphasis is given on the extension of aus cultivation throughout the country. The present field study tested yield and morphological attributes of six developed aus rice varieties viz. Binadhan-14, Binadhan-19, BRRI dhan43, BRRI dhan48, BRRI dhan55 and BRRI dhan65 to characterize yield, maturity and phenological properties. The field trial was set at Satvaiyapara of Khagrachari during 2018 following Randomized Complete Block design with dispersed plots. All data were collected at harvest and analysed statistically by Statistix 10. Findings revealed that statistically highest grain yield was produced from BRRI dhan55 (4.49 t/ha) and BRRI dhan48 (4.48 t/ha); the lowest by BRRI dhan65 (3.06 t/ ha). The yield of Binadhan-19 (4.37 t/ha) and Binadhan-14 (3.87 t/ha) was intermediate. In case of maturity, Binadhan-19 (99.33 days) had the shortest life duration and BRRI dhan48 (113.67 days), the longest. The greater portion of the farmers was keen to grow Binadhan-19 and Binadhan-14 instead of BRRI dhan43 and BRRI dhan48 mainly for its short duration, optimal yield, long and slender quality grain. Binadhan-19 might be a promising aus variety in the Khagrachari hill tracts for gaining favourable yield within a short time. Therefore, further studies are needed in jhum cultivation with local cultivars for more significant comparison and acceptability to the rice farming community.

\section{Introduction}

Rice is the prime food for over 50\% of the global population (1). It plays a commanding role by accounting about $91 \%$ of total food grain production in Bangladesh. Over $99 \%$ of people eat rice as main food (416 gm/person/day) (2). Rice production has doubled in the last 30 years with the development of high-yielding, short duration, stress-tolerant, resourceresponsive and semi-dwarf varieties. However, the threat of a food crisis remains due to an everincreasing population, water scarcity, shortage of labour, climate change, pest/diseases, conversion of agricultural land to housing, industries, flash flood, increasing incidences of drought, uneven distribution of rainfall, soil erosion, soil degradation and environmental issues. Above all, drought is predicted to be the most severe stress that reduces rice yield (3). Aus, aman and boro are three rice growing seasons of Bangladesh. Among them, aus is least produced due to prevailing drought and limitations for irrigation $(1,4)$. Majority of the grown aus rice are modern varieties developed by BRRI (Bangladesh Rice Research Institute), and BINA (Bangladesh Institute of Nuclear Agriculture); which occupies almost 85\% and a minor amount covers local or indigenous cultivars which are approximately $15 \%$ of the total rice-growing area (5). Among the three hill tract districts of Bangladesh;

(c) Chowhan et al (2021). This is an open-access article distributed under the terms of the Creative Commons Attribution License, which permits unrestricted use, distribution and reproduction in any medium, provided the original author and source are credited (https://creativecommons.org/licenses/by/4.0/).

To cite this article: Chowhan S, Ali M K J, Nahar K, Rahman M M, Ali M I, Islam M. Yield and morpho physical characters of some modern aus rice varieties at Khagrachari. Plant Science Today. 2021;8(1):155-160. https://doi.org/10.14719/pst.2021.8.1.984 
Khagrachari occupies almost one fifth $\left(2700 \mathrm{~km}^{2}\right)$ in terms of total land area (6). Aus rice is mostly cultivated in the valleys by seedling transplanting and in hills as direct-seeded (jhum farming) after first rainfall at the beginning of Kharif season commonly from April to May (7). Due to lack of enough adaptation and preference by the hill farmers; the HYVs (high yielding variety) are not widely cultivated here. The total area under rice cultivation was 11520000 ha during 2018-19; where aus was 9.6\%. In Khagrachari hill tract local cultivars of aus rice were cultivated in 2271 hectares whose mean yield was $2.21 \mathrm{t} / \mathrm{ha}$ and HYV grown in 1756 ha yield was 2.60 $\mathrm{t} /$ ha. National average of aus yield is $2.51 \mathrm{t} / \mathrm{ha}$ (BBS, 2019) but according to FAOSTAT (8) dehusked yield of aus rice is $3.15 \mathrm{t} / \mathrm{h}$. Though local aus cultivars are of low yield, due to adoption of modern rice production technologies yield has been enhancing gradually. Area and production of aus rice have decreased compared to boro, which is the major rice crop in Bangladesh. Production of boro rice is irrigation depended whose source is generally groundwater, which ultimately results in the declination of the water table. However, aus rice requires just 5\% supplement irrigation and puts almost no pressure on groundwater. Consequently, aus rice is far more water-saving than boro. It is imperative to convert boro growing area to aus keeping the food security of the country in mind (2).

There is an acute problem of surface and subsurface water for irrigation in Khagrchari during the dry season. Thus, for rice production in this season selection of suitable drought-tolerant and less input requiring variety is of prime concern. Most of the traditional cultivars are well adapted to drought stress, but these are of low yielding and more duration. BRRI and BINA have developed some modern varieties viz. BRRI dhan43, BRRI dhan48, BRRI dhan55, BRRI dhan65, BRRI dhan83, Binadhan19, Binadhan-21 which have a higher yield, shorter life cycle and tolerant to water deficit conditions. This observation trial was executed to assess yield, phenological attributes of modern aus rice varieties, taking into account of the above factors.

\section{Materials and Methods}

\section{Experimental site and management}

The field experiment was carried out at farmers field of Perachhara under Sadar upazila of Khagrachari hill district during aus season of 2018 (April to July). It comes under the agro-ecological zone (AEZ) 29, i.e., Northern and eastern hills (9). The geographical position of the trial plot $\left(23^{\circ} 06^{\prime} 31.1^{\prime \prime} \mathrm{N} 92^{\circ} 00^{\prime} 22.6^{\prime \prime E}\right)$ was subtropical climate distinguished by mediumhigh temperature and high rainfall during Kharif season (March to October) and low rainfall and temperature in rabi season (November to February). Randomized Complete Block design with dispersed plots was followed for experimentation. Each varietal plot consisted of half (0.5) bigha i.e. $1349 \mathrm{~m}^{2}$. So, for six varieties (Binadhan-14, Binadhan-19, BRRI dhan43, BRRI dhan48, BRRI dhan55 and BRRI dhan65) there were six different plots. Pregerminated seeds were sown on April 04, 2018 in seedbed then seedlings were transplanted at 25 DAS (days after seeding) in the main field using two to three seedlings per hill. For fertilization, yield goal: $4.0 \pm 0.4 \mathrm{t} / \mathrm{ha}$ and soil analysis interpretation 'low' was considered, according to FRG (10). Row to row and plant to plant distance was $20 \times 15 \mathrm{~cm}$. To control initial weeds, pre-emergence weedicide Rifit 500 EC @ $988 \mathrm{~mL} / \mathrm{ha}$ was applied (6). Later two hand weeding was done at 30 DAT (days after transplanting) and 45 DAT. Irrigation was applied when upper soil completely dried and cracked. $10 \mathrm{~kg}$ of granular Carbofuran-5G per hectare was applied with urea top dressing for preventing stemborer and other insect infestation (11). Fungal diseases were checked by applying Tilt 250 EC and Amistar Top @ $500 \mathrm{~mL} / \mathrm{ha}$. Grass-hopper, rice bug and sucking/biting type insects were controlled by spraying Ripcord 10 EC @ $988 \mathrm{~mL} / \mathrm{ha}$ (12). Details of the weather data such as temperature, rainfall and relative humidity of the trial location are shown in Fig. 1 (13).

\section{Data collection and analysis}

Crops were harvested when $90 \%$ of the grains became golden colour. Randomly ten plants were

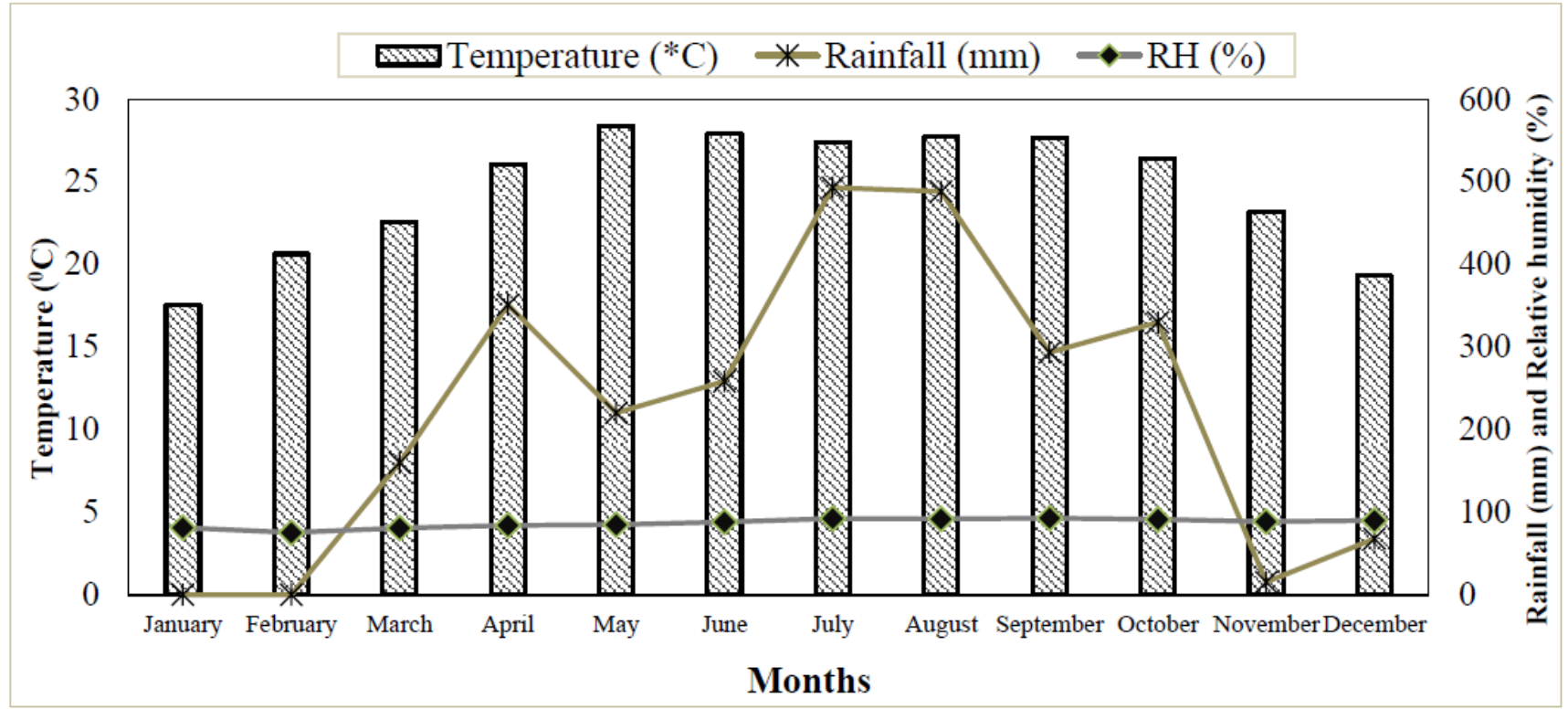

Fig. 1. Weather data of the experimental site. Source: BINA (13). 
selected from each plot and data were collected on plant height $(\mathrm{cm})$, number of total tiller/hill, number of non-effective tiller/hill, number of total leaves /hill, number of panicles/hill, panicle length $(\mathrm{cm})$, panicle weight (gm), panicles $/ \mathrm{m}^{2}$, root length $\left(\mathrm{cm}^{2}\right)$, number of grains/panicle, grain sterility(\%), TGW [thousand grain-weight (gm)], HI [harvesting index (\%)], grain yield $(\mathrm{t} / \mathrm{ha})$, straw yield $(\mathrm{t} / \mathrm{ha})$, biological yield $(\mathrm{t} / \mathrm{ha})$ and duration to maturity (days). HI (\%) was enumerated, according to the standard formula (14). Grain yield was adjusted at $14 \%$ water content and straw yield at the sun-dry basis. Later, all the collected data were statistically separately analyzed by using ANOVA (analysis of variance) technique through Statistix 10 software (15). Significance of mean difference was compared by LSD (least significant difference) test (16) at 5\% level of probability.

\section{Results and Discussion}

\section{Growth and phenological attributes}

Details of different parameters related to agronomic and phenological characteristics are given in Table 1, whose results and discussion are sequentially explained below.

Plant height remained unchanged among all the varieties except BRRI dhan65. It was the shortest $(91.80 \mathrm{~cm})$ height compared to others. It was reported that, plant height of BRRI dhan65 was about $88 \mathrm{~cm}$; which was close to the present result (17). Height being a genetical trait remains unchanged in uniform soil and environmental conditions. Binadhan-19 (17.00) produced the maximum number of total tillers/hill, followed by Binadhan-14 (13.74). BRRI dhan43 (8.20) had the least number of total tillers/hill and was statistically identical to BRRI dhan48, BRRI dhan55 and BRRI dhan65. BINA (18) stated that the number of total tillers/hill was 17 in Binadhan-19. As per a study it was found that the mean total tiller of BRRI dhan48 was 4.50 (19). Binadhan-19 exhibited a total of 13.53 numbers of tiller/plant during boro season (1). It was also noticed a variation in the number of total tillers/hill due to varietal differences (20).

A statistically identical number of most noneffective tillers/hill was seen with BRRI dhan55 (1.43) and Binadhan-14 (1.41) followed by BRRI dhan48 (0.93), BRRI dhan65 (0.90) and BRRI dhan43 (0.67). The fewest number of non-effective tillers/hill was originated by Binadhan-19 (0.38) which was statistically different from the rest of the varieties. Binadhan-19 produced 1.00 number of non-effective tiller/hill at $25 \times 20 \mathrm{~cm}^{2}$ spacing (14). There are reports on 6.7 numbers of non-effective tiller/hill with BRRI dhan65 with varietal effect (21). Changes in non-effective tiller might be due to varietal character, weather factor and soil nutrient status.

The highest number of total leaves/hill was recorded with BRRI dhan48 (45.13) and Binadhan-14 (42.93) which were statistically same. The lowest number of leaves was found in BRRI dhan43 (27.80). Dissimilarities in leaf numbers may have happened for individual varietal growth, nutrient use efficiency and genetic traits.

The number of panicles/hill was higher in Binadhan-19 (16.62) and lower in BRRI dhan55 (8.86), BRRI dhan65 (8.60) and BRRI dhan43 (7.53). It was revealed that BRRI dhan48 produced a greater number of panicles than BRRI dhan43; which is in affirmatory with present findings (22). There were no significant distinctions in panicle length among the studied varieties. This might be unchanged because of varietal character.

Maximal panicle weight resulted from BRRI dhan48 (25.33 gm) followed by BRRI dhan55 (19.93 $\mathrm{gm})$ and statistically identical minimal was recorded with varieties, Binadhan-14 (15.77 gm), BRRI dhan43 (15.30 gm), BRRI dhan65 (13.00 gm) and Binadhan-19 (12.47 gm). Reports are on the panicle weight of four boro rice varieties between 15.33-23.33 gm, which more or less supported the present outcome (1). The number of panicles $/ \mathrm{m}^{2}$ was maximum in Binadhan14 (376.83) and minimum in BRRI dhan65 (239.33). It

Table 1. Growth and yield attributes of six high yielding aus rice varieties.

\begin{tabular}{|c|c|c|c|c|c|c|c|c|c|c|c|c|c|}
\hline Variety & 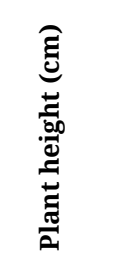 & 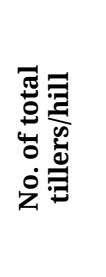 & 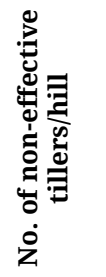 & 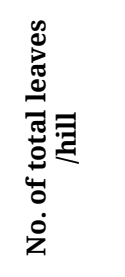 & 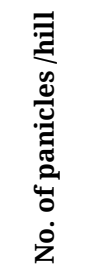 & 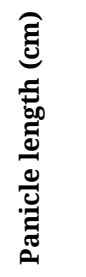 & 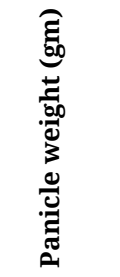 & 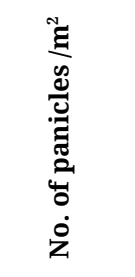 & 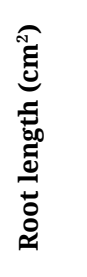 & 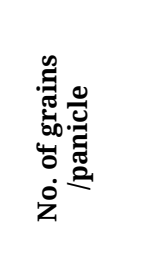 & 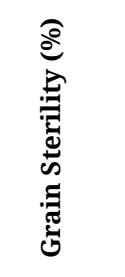 & $\begin{array}{l}\text { ప్ర్య } \\
\text { ప్ర }\end{array}$ & $\underbrace{\stackrel{0}{e}}$ \\
\hline Binadhan-19 & $102.28 \mathrm{a}$ & $17.00 \mathrm{a}$ & $0.38 \mathrm{~b}$ & $36.82 \mathrm{ab}$ & $16.62 \mathrm{a}$ & 19.58 & $12.47 \mathrm{~b}$ & $318.00 \mathrm{ab}$ & 16.53 & $174.18 \mathrm{bc}$ & $28.39 \mathrm{ab}$ & $19.46 \mathrm{~b}$ & 46.39 \\
\hline Binadhan-14 & $101.23 \mathrm{a}$ & $13.74 \mathrm{~b}$ & $1.41 \mathrm{a}$ & $42.93 \mathrm{a}$ & $12.33 \mathrm{~b}$ & 23.97 & $15.77 \mathrm{~b}$ & $376.83 \mathrm{a}$ & 9.49 & $176.17 \mathrm{bc}$ & $32.46 \mathrm{a}$ & $25.24 \mathrm{ab}$ & 39.33 \\
\hline BRRI dhan43 & $105.70 \mathrm{a}$ & $8.20 \mathrm{c}$ & $0.67 \mathrm{ab}$ & $27.80 \mathrm{c}$ & $7.53 \mathrm{c}$ & 22.03 & $15.30 \mathrm{~b}$ & $276.67 \mathrm{ab}$ & 9.56 & $145.54 \mathrm{c}$ & $24.57 \mathrm{~b}$ & $27.01 \mathrm{a}$ & 43.07 \\
\hline BRRI dhan48 & $102.70 \mathrm{a}$ & $10.47 \mathrm{c}$ & $0.93 \mathrm{ab}$ & $45.13 \mathrm{a}$ & $9.54 \mathrm{bc}$ & 23.83 & $25.33 \mathrm{a}$ & $262.73 \mathrm{ab}$ & 8.65 & $225.35 \mathrm{ab}$ & $25.12 \mathrm{~b}$ & $25.54 \mathrm{ab}$ & 32.75 \\
\hline BRRI dhan55 & $101.72 \mathrm{a}$ & $10.29 \mathrm{c}$ & $1.43 \mathrm{a}$ & $32.53 \mathrm{bc}$ & $8.86 \mathrm{c}$ & 21.71 & $19.93 \mathrm{ab}$ & $273.19 \mathrm{ab}$ & 12.46 & $261.85 \mathrm{a}$ & $25.75 \mathrm{ab}$ & $24.83 \mathrm{ab}$ & 46.62 \\
\hline BRRI dhan65 & $91.80 \mathrm{~b}$ & $9.49 \mathrm{c}$ & $0.90 \mathrm{ab}$ & $32.64 \mathrm{bc}$ & $8.60 \mathrm{c}$ & 20.16 & $13.00 \mathrm{~b}$ & $239.33 \mathrm{~b}$ & 9.64 & $190.63 \mathrm{bc}$ & $27.71 \mathrm{ab}$ & $23.95 \mathrm{ab}$ & 42.62 \\
\hline LSD (5\%) & 7.21 & 3.21 & 0.81 & 8.57 & 3.15 & 4.56 & 8.91 & 121.64 & 7.89 & 61.33 & 7.25 & 7.06 & 13.52 \\
\hline $\begin{array}{l}\text { Standard Error } \\
\text { (SE) }\end{array}$ & 3.24 & 1.44 & 0.36 & 3.84 & 1.41 & 2.05 & 3.99 & 54.60 & 3.54 & 27.52 & 3.25 & 3.17 & 6.06 \\
\hline $\begin{array}{l}\text { Level of } \\
\text { Significance }\end{array}$ & * & $*$ & $*$ & * & * & NS & $*$ & $*$ & NS & $*$ & * & $*$ & NS \\
\hline CV (\%) & 3.93 & 15.31 & 46.82 & 12.97 & 16.07 & 11.46 & 28.86 & 22.97 & 39.24 & 17.23 & 14.57 & 15.94 & 17.48 \\
\hline
\end{tabular}

Means bearing same letter(s) in a column do not differ significantly at 5\% level of probability by LSD.

NS- Non-Significant 
was observed that panicles number per square meter ranged from 235-305 (23). Studies also shows that 403.79 panicles $/ \mathrm{m}^{2}$ of Binadhan-14 in boro season (1). Differences in panicle numbers may be dependent on the season; thus, such variation was noted.

No statistical distinction in root length was noticed in the varieties. Soil moisture, nutrient and land type structure is mainly responsible for root followed by BRRI dhan48 (4.48 t/ha), Binadhan-19 (4.37 t/ha), Binadhan-14 (3.87 t/ha), BRRI dhan43 (3.54 $\mathrm{t} / \mathrm{ha}$ ). The least amount of grain yield was obtained from BRRI dhan65 (3.06 t/ha). It was stated that the grain yield of BRRI dhan 48 was significantly higher than BRRI dhan43 (27). In a field trial of aus rice varieties found that yield of BRRI dhan 48 was 4.70 $\mathrm{t} / \mathrm{ha}$ and Binadhan-19 was $4.38 \mathrm{t} / \mathrm{ha}$ (28). There are observations that yield of Binadhan-14 was $4.32 \mathrm{t} / \mathrm{ha}$

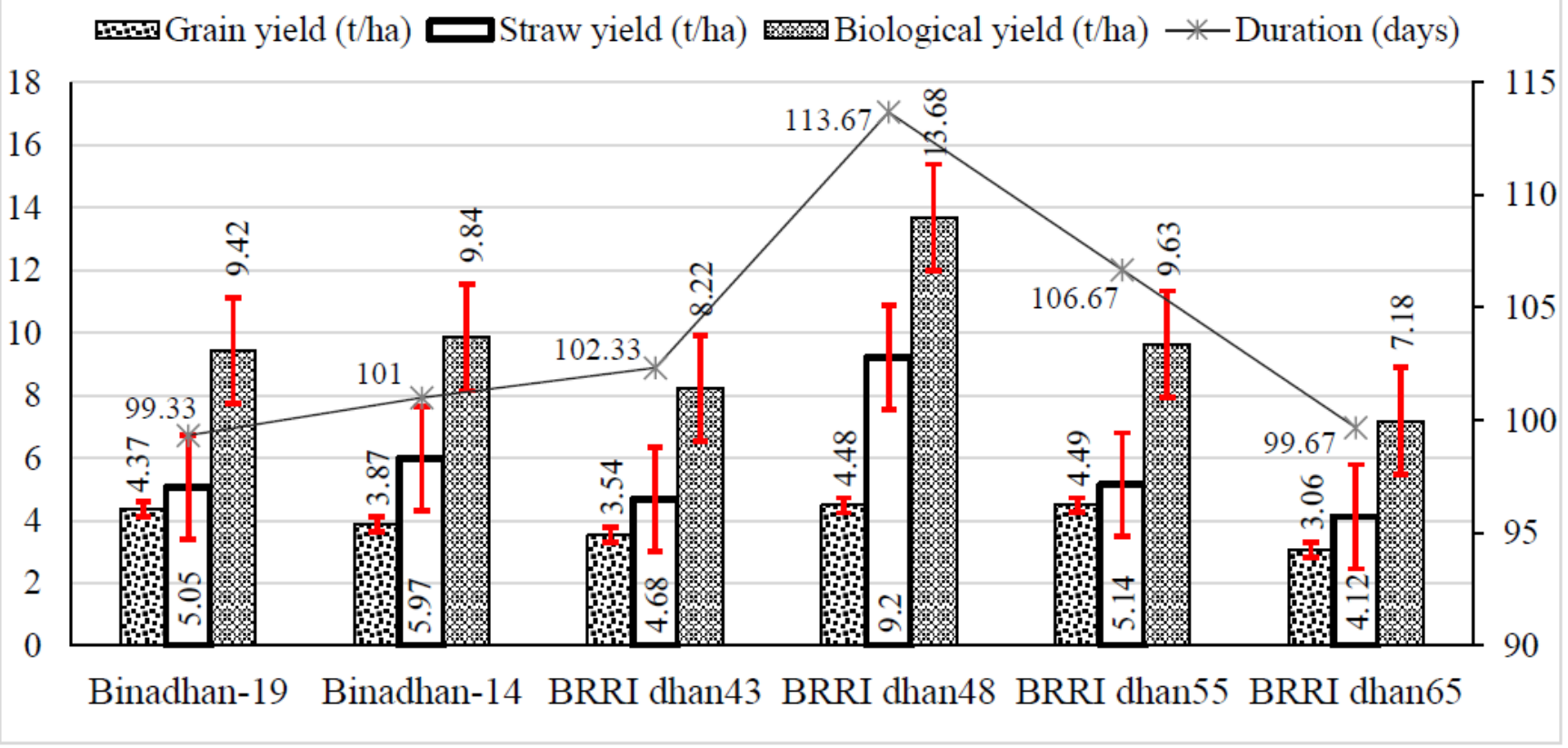

Fig. 2. Yield and duration of modern aus rice varieties.

growth and development. The number of grains/panicle was most in BRRI dhan55 (261.85) and least in BRRI dhan43 (145.54). It was observed that grain number per rice panicle in aus rice was 68.75149.94 (7), whereas, studies are there that noticed this extent 62.27-136.30 (19). Alternatives in grain numbers/panicle might be due to varietal influences.

More grain sterility (\%) was noted in Binadhan14 (32.46\%); less in BRRI dhan48 (25.12\%) and BRRI dhan43 (24.57\%). Similar sterility (\%) was found in Binadhan-14 (32.80\%) at boro season (1). Grain sterility varied significantly by variety (24). Usually, $15-20 \%$ of sterile grains are produced in healthy rice (25). The present result was in conformity of this. Heaviest thousand-grain weight (TGW) was produced by BRRI dhan43 (27.01 gm) and lightest by Binadhan19 (19.46 gm). BRRI (26) reported that the average 1000 seed weight of BRRI dhan43 was $21.30 \mathrm{gm}$ and BINA (18) disclosed that, mean TGW of Binadhan-19 was $24.10 \mathrm{gm}$ as transplanting aus. Distinctions in TGW may have taken place for factors like grain filling and phosphorus nutrient.

Harvesting index (\%) was found to be nonsignificant among the varieties. May be grain and straw yield of the varieties had slight difference thus $\mathrm{HI}(\%)$ remained unchanged.

\section{Yield and maturity duration}

Various yield components of six aus rice varieties with their life duration are exhibited in Fig. 2. BRRI dhan55 yielded maximum grain yield (4.49 t/ha) with varietal effect in boro season (29). However, in the present trial due to shorter life duration in aus yield of Binadhan-14 was lesser. Varietal disparities in grain yield were mainly due to grain size, shape, tillering potential, sterility (\%) and crop duration.

Maximum stover and biological yield were produced by BRRI dhan48 (9.20 t/ha and $13.68 \mathrm{t} / \mathrm{ha}$ ), second highest by Binadhan-14 (5.97 t/ha and 9.84 t/ha), third-highest from BRRI dhan55 (5.14 t/ha and $9.63 \mathrm{t} / \mathrm{ha}$ ) followed by Binadhan-19 (5.05 t/ha and 9.42 t/ha), BRRI dhan43 (4.68 t/ha and 8.22 t/ha). Contrary, the minimum straw and biological yield were gained from BRRI dhan65 (4.12 t/ha and $7.18 \mathrm{t} / \mathrm{ha})$. The grain of BRRI dhan65 is moderately fine and for less tillering capacity, it had the lowest stover and biological yield. Studies indicated that variable biological yield (6.53 t/ha to $9.52 \mathrm{t} / \mathrm{ha}$ ) under different transplanting dates (30). In an experiment, it was stated that with varietal effect; straw and biological yield of BRRI dhan65 was $6.76 \mathrm{t} / \mathrm{ha}$ and $9.41 \mathrm{t} / \mathrm{ha}$ respectively (21). Studies are there revealing $6.88 \mathrm{t} / \mathrm{ha}$ and $10.85 \mathrm{t} / \mathrm{ha}$ (27). A study proposed $7.53 \mathrm{t} / \mathrm{ha}$ and $12.15 \mathrm{t} /$ ha straw and biological yield respectively on BRRI dhan48 (7). BRRI dhan43's 3.78 t/ha and 6.49 t/ha stover and biological yield were recorded (27). Reports are on $7.30 \mathrm{t} / \mathrm{ha}$ and $12.15 \mathrm{t} / \mathrm{ha}$ stover and biological out-turn of Binadhan-14 during boro season (1). The present results are more or less affirmatory with previous findings. Inequalities in stover and biological yield might be due to growing season, crop duration, tillering number, number of filled spikelets, soil nutrient status etc. 
In terms of maturity duration, BRRI dhan48 took the longest time to mature (113.67 days), BRRI dhan55 had the second-longest life cycle (106.67 days) which was a week earlier than BRRI dhan48. BRRI dhan43 matured at 102.33 DAS followed by Binadhan-14 (101 days), BRRI dhan65 (99.67 days). Earliest maturity was found with Binadhan-19 (99.33 days) which matured almost two weeks before than BRRI dhan48. BRKB (31) reported mean life duration of BRRI dhan48 was 110 days, BRRI dhan55 and BRRI dhan43 were 100 days, BRRI dhan65 was 88 days to 100 days. Earlier field demonstrations from BINA (18) alluded, average growth duration of Binadhan-19 was 100 days, and Binadhan-14 was 103 days. Findings of this current investigation verified that it was closely in conformity with the past research results. The duration may have varied due to weather factors, soil moisture and seasonal changes.

\section{Conclusion}

Though jhum farmers mostly prefer local indigenous cultivars like Chorui, Bobboi, Company, Horinbinni, Kamarangdhan, Gallongbinni etc. as aus rice in the hilly lands; in valleys, the modern varieties developed by BRRI and BINA are performing significantly better than the local cultivars in terms of yield, duration, tolerance to stress and grain quality. The greater portion of the plain land aus farmers was biased to grow Binadhan-19 and Binadhan-14 due to short duration, satisfactory yield and premium grain quality. In contrast, the majority of the jhum farmers prefer indigenous cultivars due to taste and flavour. On the other hand, there are minimal studies with MVs in jhum cultivation. As a result, more and further studies like this are needed in the hilly ecosystem; for that crop, synchronization should be kept in mind as the duration of local cultivars are much longer than the MVs. Appropriate rice breeding programs should also be taken to develop taste and flavour based rice varieties feasible for jhum cultivation in the hilly areas of Chittangong Hill Tracts.

\section{Acknowledgements}

Authors would like to express utmost appreciation, gratitude and heartfelt thanks to Ongkio Marma, Field man, BINA Sub-station, Khagrachari and Dolan Kanthi Mallick, Sub Assistant Agriculture Officer of the Department of Agricultural Extension for their helpful cooperation throughout the entire research work. We are also grateful to the Bangladesh Institute of Nuclear Agriculture for providing necessary supports to conduct this field investigation.

\section{Authors' contributions}

All the authors jointly conceptualized and cooperated the experimental strategy. SC designed, finalized and carried out the field study. MKJA, KN and MMR collected the necessary review of the literature and drafted the introduction and methodology part of the article. MIA and MI collected, encoded, entered the raw data in excel and wrote the conclusion and citation segment. SC did the statistical analysis, wrote results and discussion portion, reviewed the final manuscript, revised and compiled the article. All authors have read, finalized and approved the final version of the paper.

\section{Conflict of interests}

Authors do not have any conflict of interests to declare.

\section{References}

1. Chowhan S, Hoque MI, Ghosh SR, Islam M, Akter MB. Effect of variety and seedling number on the growth and yield of boro rice in Bangladesh. Journal of Experimental Agriculture International. 2019;41(6):1-15. https://doi.org/10.9734/jeai/2019/ v41i630436

2. Rahman N, Hasan M, Hossain M, Baten M, Hosen S, Ali M, Kabir M. Forecasting aus rice area and production in Bangladesh using Box-Jenkins approach. Bangladesh Rice Journal. 2016;20(1):1-10. https://doi.org/10.3329/brj.v20i1.30623

3. Sandhu N, Kumar A. Bridging the Rice Yield gaps under drought: qtls, genes and their use in breeding programs. Agronomy. 2017;7(2):1-27. https://doi.org/10.3390/agronomy7020027

4. Chowhan S, Ali MKJ, Nahar K, Rahman MM, Ali MI, Islam M. Yield and morphological feature of high yielding aus rice varieties at Khagrachari hill tract In: Proceedings of the International Conference on Agriculture, Environmental and Rural Development (AERD); 2020 July 22-23; India. p. 38-39. https://doi.org/10.22161/conf.aerd.2020

5. BBS (Bangladesh Bureau of Statistics). Yearbook of Agricultural Statistics-2019. $31^{\text {st }}$ Series, Planning Division, Ministry of Planning, Dhaka, Bangladesh; 2020. p. 1-66. Available from: http://bbs.portal.gov.bd/sites/default/files/files/bbs.portal.gov.b d/page/1b1eb817_9325_4354_a756_3d18412203e2/2020-10-0609-58-453f7e0a42348e05f0999979870ec07b.pdf

6. Chowhan S, Haider MR, Hasan AFMF, Hoque MI, Kamruzzaman M, Gupta R. Comparative on farm performance of five modern rice varieties with two local cultivars. Journal of Bioscience and Agriculture Research. 2017;13(01):1074-86. https://doi.org/10.18801/jbar.130117.131

7. Chowhan S, Gupta R, Islam MM, Begum SN. Evaluation of NERICA rice mutant in jhum cultivation. Int J Agron Agri Res. 2018;12(2):24-31. https://innspub.net/ijaar/evaluation-nericarice-mutant-jhum-cultivation/

8. FAOSTAT (Statistics Division, Food and Agriculture Organization of the United Nations). Crops-Rice; 2020 [cited 2020 Sep 29]. Available from: http://www.fao.org/faostat/en/\#data/QC

9. Ahmmed S, Jahiruddin M, Sultana R, Begum RA, Biswas JC Rahman ASMM, et al. Fertilizer Recommendation Guide-2018. ISBN: 984-500-029-1, Bangladesh Agricultural Research Council (BARC), Farmgate, Dhaka 1215. p. 01-223.

10. FRG (Fertilizer Recommendation Guide). Bangladesh Agricultural Research Council (BARC), ISBN: 978-984-500-000-0, Farmgate, Dhaka-1215. 2012; p. 01-274.

11. Paul SK, Roy B, Hasan AK, Sarkar MAR. Yield and yield components of short duration transplant aus rice (cv. Parija) as influenced by plant spacing and nitrogen level. Fundamental and Applied Agriculture. 2017;2(2):233-36.

12. Khatun, S, Mondal MMA, Khalil MI, Roknuzzaman M, Mollah MMI. Growth and yield performance of six aman rice varieties of Bangladesh. Asian Research Journal of Agriculture. 2020;12(2):1-7. https://doi.org/10.9734/arja/2020/v12i230077

13. BINA (Bangladesh Institute of Nuclear Agriculture), Weather status, HOBOlink cctf-khagrachori, 2019; [cited 2019 Sep 01]. Available from: https://hobolink.com/p/b82909d639dbdd5f400a7f2a5b54b5a0 
14. Akondo MR, Hossain MB. Effect of spacing on the performance of newly developed aus rice var. Binadhan-19. Research in Agriculture Livestock and Fisheries. 2020;6(3):373-78. https://doi.org/10.3329/ralf.v6i3.44802

15. Statistix- Data analysis software for researchers (Version 10.0) Analytical Software, 2105 Miller Landing Rd, Tallahassee Florida 32312, USA, 2020. https://www.statistix.com/

16. Russell DF. MSTAT-C computer package programme. Crop and Soil Sci Dept., Michigan State Univ., USA; 1986.

17. Rahman N, Mamun M, Ahmed R, Hossain M, Qayum M, Aziz M, Hossain M, Kabir M. Stability and adaptability analysis of BRRI developed aus varieties in different locations of Bangladesh. $\begin{array}{lll}\text { Bangladesh Rice Journal. 2020;2(1):65-72. } & \end{array}$ https://doi.org/10.3329/brj.v22i1.41839

18. BINA (Bangladesh Institute of Nuclear Agriculture). Annual Report of 2018-19. 2019a; p. 01-485. Available from: http://www.bina.gov.bd/sites/default/files/files/bina.portal.gov. bd/annual_reports/29647119_9b8f_4a9a_8389_d45ea631a6cd/ annual\%20report-2018-19.pdf

19. Das GC, Samanta SC, Biswas P, Saha NK. Bhattacharya J. Effects of sowing methods on yield attributes and yield of aus rice under the tidal ecosystem. Journal of Bioscience and Agriculture Research. 2015;04(01):01-09.

20. Dey R, Biswas M, N. Hossain Miah M, Mandal P. Agronomic performances of rice varieties at different transplanting ages. International Journal of Plant \& Soil Science. 2018;6(3):124-39. https://doi.org/10.9734/IJPSS/2015/13371

21. Osman MA, Hossen K, Chowdhury RH, Tabassum CN, Islam MK, Ahmed R, Ferdous T. Assessment of different weed control methods on growth and yield performance of $\mathrm{T}$. aus rice. agricultural Research \& Technology Open Access Journal 2020;24(3): 87-92. https://doi.org/10.19080/ARTOAJ.2020.24.556267

22. Morshed N. Growth and yield of transplant aus rice as influenced by variety and number of seedlings per hill. Agronomy MS [thesis]. Dhaka, Bangladesh: Sher-e-Bangla Agricultural University; 2010. Available from: http://www.saulibrary.edu.bd/daatj/public/index.php/getDown load/SAU201001_24-08-03266_11.pdf

23. Khatun S, Biswas PS, Rahman MA, Islam MR, Salam MA. BRRI dhan42 and BRRI dhan43: Two upland rice varieties for drought prone environment. International Journal of Bio Research. 2008;4(5):48-51. Available from https://www.researchgate.net/publication/280940978_BRRI_dh an42_and_BRRI_dhan43_Two_upland_rice_varieties_for_droug ht_prone_environment

24. Sohel M, Siddique M, Asaduzzaman M, Alam M, Karim M. Varietal performance of transplant aman rice under different hill densities. Bangladesh Journal of Agricultural Research 2009;34(1):33-39. https://doi.org/10.3329/bjar.v34i1.5750

25. BRKB (Bangladesh Rice knowledge Bank). Rice production problem, 5th edition. 2016; [cited 2017 Jan 13] p.70. Available from: $\quad$ http://knowledgebank-brri.org/Publications/Riceproduction-problem/booklet-rice-production-problem.pdf

26. BRRI (Bangladesh Rice Research Institute). Annual Report of Bangladesh Rice Research Institute 2016-2017. BRRI, Gazipur 1701, Bangladesh, 2017; p. 01-412. Available from http://brri.portal.gov.bd/sites/default/files/files/brri.portal.gov. bd/page/9728b868_efc7_4f0f_926b_bbd4dc7638e3/ annual_report_2016-17_f.pdf

27. Roy TS, Pulok MAI, Rahman MM, Hussain MA, Khatun S. Effect of varieties and row spacing on the growth and yield of aus rice. Bangladesh Research Publications Journal. 2014;10(2):138-44.

28. Rakib A, Khanom MSR, Akter KT, Khatun S, Kamruzzaman M. Study of yield and yield attributing characters of some modern Aus varieties. International Journal of Applied Research. 2019;5:141-44.

29. Jewel MH, Rahman MR, Rahman MM, Islam MJ. Effect of variety and date of harvesting on yield performance of boro rice. Fundamental and Appied Agriculture, 2016;1(2):66-69.

30. Hosain MT, Ahamed KU, Haque MM, Islam MM, Bari ASMF, Mahmud JA. Performance of hybrid rice (Oryza sativa L.) varieties at different transplanting dates in Aus season. Applied Science Reports. 2014;5(1):5-8. https://doi.org/10.15192/ PSCP.ASR.2014.1.1.14

31. BRKB (Bangladesh Rice knowledge Bank). Aus Rice Varieties (BRRI dhan43, BRRI dhan48, BRRI dhan55, BRRI dhan65). 2020; [cited 2020 Oct 6] Available from: http://knowledgebankbrri.org/brri-rice-varieties/aus-rice-varieties/ 